\title{
GENRE PECULIARITIES AND THE SYSTEM OF CHARACTERS IN THE PLAY A MIDSUMMER NIGHT'S DREAM BY W. SHAKESPEARE
}

\author{
Svitlana Maslova \\ $\mathrm{PhD}$, Assistant Professor, Odessa National Maritime University, Ukraine \\ e-mail: stephaniabw@ukr.net,orcid.org/0000-0002-3600-8501
}

\section{Summary}

The article is focused on genre peculiarities of a comedy A Midsummer Night's Dream by W. Shakespeare and its essential features within the genre of the drama. It is defined that an important aspect of combining such factors as characters and structure, themes and motifs of the play under the analysis makes the plot interesting and catching. Due to some innovative approach the author, on the one hand, tries to separate themes from motifs but at the same time shows how they are entwined and merge when the structure needs it. The author assumes that the major themes of the play are: love and marriage, fantasy and reality, order and disorder. It is also proved that a comedy A Midsummer Night's Dream offers intrepid contrasts, diverse plot components, climatic atmosphere and colourful characters.

Keywords: genre peculiarities, comedy, characters, structure of the play, themes and motifs.

DOI: https://doi.org/10.23856/3850

\section{Introduction}

A Midsummer Night's Dream is an example of Shakespearean comedy which deals with several sets of lovers who must go through obstacles and misunderstandings before they are finally united in marriage. The play's central couples, Hermia and Lysander and Helena and Demetrius, begin the play facing two classic obstacles of Shakespearean comedy: parental disapproval and misdirected love. Hermia's father forbids her to marry Lysander, insisting that she marry Demetrius instead. According to Athenian law, Hermia faces death or exile if she disobeys her father. Meanwhile, Helena loves Demetrius, but his love is currently directed at Hermia. These initial obstacles become confused and compounded when the couples enter the forest. The fairy Puck's mistaken enchantments result first in Lysander loving Helena, and finally the play ends as all Shakespearean comedies do: with a wedding.

Like other Shakespearian comedies, A Midsummer Night's Dream focuses on the characters' situations rather than their emotions (Babelyuk, 2017; Edwards, 2001). For example, in the play's first scene, being in despair because they are forbidden to be together, Hermia and Lysander focus not on their feelings, but on a solution: make a secret plan to escape. Later, the fairy king Oberon witnesses Helena pledging her devotion to Demetrius and immediately decides to intervene when Demetrius harshly rejects her. Both the lovers' decision to go into the forest and the fairies' decision to intercede in the lovers' lives create a difficult situation that confuses and troubles the lovers. Confident in the idea that the magical mistakes will finally be corrected and that order will be restored, the reader enjoys watching the drama unfold.

In a nutshell the comedy under analysis combines unique worlds which are not usually merged together, some obvious and sharp contrasts. That's why some scholars believe that if it had not been for the hands and writing skills of Shakespeare the play might have been destroyed by the lack of balance. The playwright nonetheless knew well how to compile antagonistic 
constituents, such as: the characters of Bottom and Puck within one play, the rough realism arising from plain artisans and the subtle gracefulness of the fairy realm, or the artistic and sharp wordplay of the Athenians and the noble behaviour of Theseus and Hyppolita.

As it is seen the contrasts in the play appear at various genre levels and in different themes and motifs. What is significant here is the fact that Shakespeare knew that there must be a reconciliation and fusion of the contradictory and ambiguous elements of the play in order to remain within the frames of the drama. Therefore, the comedy A Midsummer Night's Dream offers intrepid contrasts, diverse plot components, climatic atmosphere and colourful characters. On the other hand, it shows that creative imagination is able to unite such contradictory factors.

Following the line of putting together various contrastive aspects, we would like to pursue this pattern and conduct the research similar in tone. Usually the investigation of William Shakespeare is either strictly linguistic or purely literary.

The aim of the present study is to combine, contrast and draw conclusions resulting from the stylistic analysis merging from both linguistic and genre aspects of the comedy $A$ Midsummer Night's Dream. Such an approach seems to be innovative enough to be worth trying. The objective of the research is to focus on presenting the play, as an example of a comedy originating from the Elizabethan epoch and showing how it integrates itself with standard features and how much it differs from them. The intention is also to confirm that only a balanced combination of linguistic and literary analysis can give the most vivid and complete picture of the play due to the absolute and accurate comprehension of the text.

\section{Characters and drama structure in the play $A$ Midsummer Night's Dream}

The play A Midsummer Night's Dream is unique in many ways as its structure comprises diverse levels of subplots and characters.

When it comes to the analysis of the connection between characters and the structure of the play one can agree that it is mostly based on the contrast rather than similarity. William Shakespeare very often "moves from one social group to another", as pointed by D. Crystal (Crystal, 2008). The author presents a gradation within society, from the Duke to ordinary people. The play may be, therefore perceived as a wide picture of the society. Shakespeare uses this structural issue to comment the society from both, the philosophical and social angle. This is how the author attributes harmony, order or balance to the way society works. However, he also proves that the high society levels do not necessarily embody perfection as a social group.

There are some inevitable connections between various characters originating from different social backgrounds (Babelyuk, 2018; Edwards, 2001). By introducing the character of Bottom, Shakespeare brought into the play a farcical and ridiculous dimension, which led to the Duke and his lover. The association that can be seen between Bottom and the Duke arises from the fact that the play itself was created to pay honour to the Duke and his wife-to-be. D. Spencer writes about the structure of the play that "the unity of place that was so important in Aristotle works triggered one sequence of events, which were focused and centred around one main character" (Spencer, 2019).

In Shakespeare's plays the structure is definitely not that simple. However, as D. Spencer adds, Shakespeare's plays are somehow unified, as "[t]hey have a central theme that may be illustrated by parallel situations among different characters in different families or social classes" (Spencer, 2019). It means that William Shakespeare was a genius in 
finding ways to see the theme from various angles and being able to combine several plots in one integrated complex structure. One of the examples presenting the major and focal point is when Lysander utters his famous words about true love while consoling Hermia in Act 1, Scene 1:

\section{"The course of true love never did run smooth" \\ (A Midsummer Night's Dream, Act 1, Scene 1)}

To our mind, the words of Lysander define the major theme of the play, which brings in no less than three groups of characters: the Duke and his companions, young lovers, born in high social classes and servants, originating from lower social classes. Besides, here there is one more group of fictional characters, which can be defined as the fairies.

All four sets of characters are involved in similar incidents and encounter analogous experiences, like love at first sight, envy, love triangles, competition, or erroneous identity. Each and every one of the occurrences mentioned above are introduced to prove Lysander words true that the feeling of love is complex. The examples of such involvedness, which is a characteristic feature of the Shakespearean comedy, can be found in many situations and characters:

(1) the story of Theseus and Hippolyta, whose tale is surrounded by the Duke and his associates;

(2) the story of young lovers, born in high social circles - Hermia and Lysander as well as Helena and Demetrius symbolize love at first sight;

(3) the story of Oberon and Titania, who are the representatives of the fairy realm and the royalty indicate envy and stubbornness in marriage;

(4) the story of Bottom and Titania embody a relationship between a fairy and the lower class born mortal, who suffer from an enchantment cast on them;

(5) the story of Pyramus and Thisbe, the nobles, who die because love went wrong.

Though the play combines five different stories the whole plot is nicely and skilfully intertwined, so that no story is diminished in its importance. However, apart from true love, discussed above, another obstacle should be mentioned: the love of parents. This is the tale of Hermia, whose father disagrees with her choice of a husband and proposes his own candidate. The disobedience with the father means severe punishment. It all ends with the escape to the forest, where the reader learns about the fairies and their realm.

By the way, the world of fairies also becomes as a multipurpose tool in Shakespeare's hands to instigate a disruption within the social circle and the tone of the play. It happens as the fairies resettle the reader and the characters to some extent, too, into the midst of the fantasy realm. The fairies and their world are responsible for igniting the bewilderment and mysticism in the forest scenes, the resolution in a magical form of the conflicts between characters, the love story among themselves as well as the blessings of the peace finally reached.

It's worth to underline, that every tale included into the play is somehow connected to the realm of the fairies and the magic they perform. D. Spencer affirms that "Shakespeare's strategy is to alternate pieces from each story, emphasizing the connections. His plays are easier to study if you comprehend each story separately, then reshuffle them to study their dependence on each other" (Spencer, 2019). However, as the author amends, "[j] ust because the plot is confused doesn't mean that Shakespeare was either confused or incompetent. On the contrary, he used confusion in the plot to illustrate the confusion in the minds of the characters. People in love, says Shakespeare, behave most irrationally [...]" (Spencer, 2019).

The conclusion of the complexity of the plot can be seen analogically to the involvedness of the feeling of true love (Edwards, 2001). Both, the plot of the play and the feeling of love can 
be characterized identically as foolish, unpredictable, perplexed, irrational and magic. A good quote to support the above declaration could be the words of Puck in Act 3, Scene 2:

"Lord, what fools these mortals be!"

\section{(A Midsummer Night's Dream, Act 3, Scene 2)}

The structure of the play is, therefore tightly connected with the plot itself. The places where the events took place are symbolic, for example the separation between the city and the woods, which in the end serves as the shelter for the characters.

By the way, the forest has been a magical place in many myths and plays and its function was to bring Elizabethan balance to the happenings. In Poetics the forest, in general, is a strong symbolic place. It refers to the roots, a return to nature, something very plain, unrefined and even primitive. On the one hand, the forest gives the feeling of freedom and independence and that is definitely an opposition to the strictness of the social laws present in the cities. It can be, therefore perceived as a place of rebirth, rethought and renewal. On the other hand, the forest may be a dangerous place, where the darkness and wilderness can flabbergast anyone. Many see the forest as a labyrinth, a maze, where anyone can lose themselves not only physically but also mentally and that is what nearly happened to Titania. Nevertheless, the same forest stands also as a place enabling to return to the state of happiness, order and harmony. It is the forest that makes the necessary passage to achieve peace and solution to all troubles.

The return to order, happiness and harmony must come at the end of the play, as it is a compulsory genre element of the comedy (Edwards, 2001). Furthermore, the structure of the play combined with its tone can be compared to a dance of the characters, in which they change partners and positions three times: the first position is the love of Hermia directed towards Lysander; the second position is the rejection of Hermia by Lysander and the fight for Helena by both Lysander and Demetrius; the third position is the characters return to harmony.

In addition to the above mentioned genre peculiarities of the play, a word should be said about the language used, as it refers to the structure of the play, as well. William Shakespeare used both prose and verse in his writings and the comedy A Midsummer Night's Dream is not an exception. The division between the language of the prose and verse, as mentioned by D. J. Snider (Snider, 2009), differentiate between social classes: the Athenian nobility members and the fairies speak in prose, whereas the Mechanicals and the rural folk use verse.

The structure of William Shakespeare's plays is tightly connected with the plot, the characters and the symbolism of various social aspects (Womack, 2006). Most characters get involved in the tale with different intensity and they usually manage to resolve their problems, more often than not with the help of the magic world. As we have seen from the analysis above, the structure, the style and the tone are extremely vital for the play, as they allow the reader or spectator to feel the reality of the drama and to see its genre nature.

\section{Key themes in the play A Midsummer Night's Dream by William Shakespeare}

Among the variety of themes presented in the play under analysis scholars, readers, viewers usually mention love, marriage, order and disorder, illusion and reality (Womack, 2006), to name just a few. The themes listed above will be given a thorough analysis in the following section.

Love and marriage seem to be very important themes in William Shakespeare's play A Midsummer Night's Dream. In Act 1 the reader finds a famous quotation already mentioned 
in this article: "The course of true love never did run smooth," which presents, to our minds, the issue of the difficulty of love. The play is far from being a romantic tale about love, which ends happily. Shakespeare used the theme of love to present its complexity (Snider, 2009). He tries to distant the reader or the viewer from various emotions in order to allow them have fun from seeing the characters' anguish and distress. As the play A Midsummer Night's Dream is a comedy, the audience and the reader are clearly sure, that in the end everything will end up well. Therefore, they can enjoy the play without being involved in the tension caused by the events and circumstances the characters find themselves in. As S. Locklear affirms, the theme of love is very often realized by the imbalance of it (Locklear, 2019), for example when pure and true love is interfered with inequality and mischief.

The asymmetry of the relationship can be seen between two couples - Hermia and Lysander and Helena and Demetrius. The tale goes not so smoothly as Hermia loves Lysander, Lysander loves Hermia and so does Demetrius. In the end one woman has too many admirers and the other one too few. The imbalance of love can also be seen among other characters, for example Titania and Oberon, who argue over the Indian foundling. Oberon believes that Titania loves the boy more than him. Later another imbalance arises when Titania, by a mischievous spell, shows her affection towards the ass-headed Bottom. The last example offers the difference between the attractiveness and elegance of Titania and awkwardness and grotesque of Bottom, as D. Locklear mentions (Locklear, 2019).

The issue of marriage is also quite complex in the play, though it changes for better in the end. The first aspect of marriage is the parental approval. Here, the story of Hermia, who is madly in love with Lysander, comes forward as an example. The two young lovers are in trouble as Hermia's father does not want his daughter to marry her lover but to wed a noble man, Demetrius. But the play ends well, as it is the comedy's genre characteristic feature, with weddings. Three couples get married: Hermia weds her beloved Lysander, Demetrius, whose magic spell was left upon him by the Fairy Queen, weds of Helena and Demetrius and Theseus and Hyppolita.

Two other of the major themes in William Shakespeare's A Midsummer Night's Dream are unquestionably order and disorder. The said themes can be found in almost every relationship that is presented in the plot. Shakespeare decided to show the order and disorder in the relationships of his characters, not matter what social status they had. For example:

the tale of Hermia and Lysander - a difficult love, as Hermia's father forbids her to marry Lysander and wants her to marry Demetrius, who here symbolises the order. If she disagrees she is bound to either nunnery or death. The two young lovers therefore escape to the forest, breaking the law and that is definitely an example of the disorder. To make matters worse, Lysander is given a love potion, destined to Demetrius, and he falls for Helena, Hermia's friend. The whole situation leads to a series of confusing conclusions, which also trigger the state of the disorder;

the tale of Helena and Demetrius - Helena, having been left by Demetrius, cannot deal with her grief and follows Demetrius to the woods. Helena's words exemplify the disorder, as it is unusual for a woman from the Elizabethan era to run after a man, regardless of the great love she may feel for him;

the tale of Titania and Oberon - a difficult love of the queen and king of the fairies, who are already married, unlike other characters of the play. However, the disorder creeps into their lives making it standing on the rocks. The disorder is seen in their arguments over various matters, like custody an Indian foundling; 
the tale of Titania and Bottom - an example of a true disorder, which is a result of a prank. Puck, who prepares the mischief, arranges that the first person Titania sees after waking up from a sleep would be an ass-headed Bottom.

In the end, the disorders that crawled into the lives of the characters are put into order again. The magic spells are all lifted from the eyes of the victims and they happily return to their previous states. So, Lysander falls back in love with Hermia, Titania and Oberon also reconcile and Demetrius falls in love with Helena. According to the genre comedy laws the play ends with an example of the order at the wedding of three couples, who are blessed by the fairy queen and king.

The next two themes that pay, to our mind, a crucial role in the play A Midsummer Night's Dream are fantasy and reality. Some scholars, readers and viewers believe that these two form the key themes of the play around which everything centres. All characters of the comedy seem to confuse fantasy world and reality at least at some point, so the two themes and the confusion set among them refer to everyone. It leads to special fiction circumstances where the characters cannot define what is real and what is only their illusion rested upon them by the magic.

By the way, the title of the play A Midsummer Night's Dream itself may enlighten the confusion that is to be read or seen in the plot, as 'dreams' are usually unreal, bewildering and obscure. The title, however, also indicates that in the end everything will end up well and that arises from the fact that the comedy was famous at the Elizabethan festival, associated with turmoil and disorder.

It's also worth underlining that Shakespeare separated the places of the plot into Athens, which symbolises the order and reality and the Woods, that stands for illusion, magic and disorder. Furthermore, the illusion and magic are so important that in order to enjoy the story, one should shelve the reality for some time and believe the illusion. The magic and the feeling of love are so powerful that through them the illusion is built. The conclusion is that love, regardless its reality and purity may deprive a man from common sense, therefore they often may have problems with differentiating between illusion and reality. One can come across numerous similar examples among them is the case of Titania, a beautiful Fairy Queen, falling in love with an ugly man, who jokingly has been transformed into an ass-headed Bottom. In reality such love, most probably, would never happen, but once magic comes in, everything seems to be possible.

Magic is used by Shakespeare for many different purposes (Edwards, 2001; Womack, 2006: 231), often contradictory ones. Therefore, it may be implied that magic can be used according to the will and in all sorts of circumstances, such as to begin the story and end it, as well. That magic is responsible not only for making the drama a comedy but also for setting the confusion. So we may sum it up that according to D. Locklear "magic is a convenient tool to bring everyone back around to normal, just as it was a convenient tool to create the comedy and confusion that gives us the plot of the play" (Locklear, 2019).

The metaphors arising from Demetrius's descriptions relate to the whole drama as well as to the theme of fantasy and reality:

"These things seem small and undistinguishable,

Like far-off mountains turnèd into clouds."

(A Midsummer Night's Dream, Act 4, Scene 1)

The mountains serve as a rock-hard and unbreakable foundation and correspond to reality, whereas clouds, being made of air symbolize illusion and something unstable, short-lived and deceptive. Elaborating on the clouds, D. Locklear atones that "[w] hen they are far away it is hard to tell what is cloud and what is the snow peaks of the mountain. This is where illusion 
and reality mix [...]" (Locklear, 2019). This is exactly what is happening in the comedy A Midsummer Night's Dream in general: the play is only catastrophic at first sight, as the audience or the reader know well that it is nothing more than illusion.

\section{Conclusions and suggestions}

The results of the research show that there is a connection between the structure and other aspects of the play such as the plot, places, where the events occur, the diversity of characters and their relationships as well as all potential feelings and emotions. Moreover, various themes and motifs, though quite different and distant from one another, when analysed individually, can smoothly link all aforementioned aspects. This approach is definitely innovative and even though quite courageous it offers a new glance at the structure and the language of the comedy under analysis.

\section{References}

Babelyuk, O. (2018). Creating A Psychological Portrait Of A Postmodern Character In English Literary Text. Odessa linguistic journal No. 11. DOI: 10.32837/2312-3192-2018-11-3-1.1 [in English].

Babelyuk, O. (2017). Culture Strategy in Translating Postmodern Literary Text. Periodyk Naukowy Akademii Polonijnej w Częstochowie, 22(3). DOI: 10.23856/2202. [in English].

Crystal, D.(2008). 'Think on my Words': Exploring Shakespeare's Language. Cambridge: Cambridge University Press. ISBN: 9781107617681.

Edwards, P. (2001). William Shakespeare, [in:] P. Rogers, The Oxford Illustrated History of English Literature. New York, Oxford: Oxford University Press. [in English].

Locklear, S. (Ed.), (2019). “A Midsummer Night's Dream - Themes”. eNotes Publishing:

eNotes.com, Inc. Retrieved from: http://www.enotes.com/topics/midsummer-nights-dream/ themes\#themes-themes-themes-themes (accessed 14 Jan 2019).

Snider, D. J., (2009) [1877]. The System of Shakespeare's Dramas. St. Louis: G. T. Jones and Company. Retrieved from: https://babel.hathitrust.org/cgi/pt?id=hvd.hwpak7;view=1up;seq=5 (accessed 26 Jan 2019).

Spencer, D. (2019). “Connecting plot into a united structure”. Retrieved from: The Professional Theatre at Southern Utah University. https://www.bard.org/study-guides/connecting-plots-into-a-united-structure (accessed 15 Dec 2018).

Womack, P. (2006). English Renaissance Drama. Oxford: Blackwell Publishing. [in English]. 